\title{
Employee Dissatisfaction and Turnover Crises in the Malaysian Hospitality Industry
}

\author{
Ahmad Rasmi Suleiman AlBattat ${ }^{1}$ \& Ahmad Puad Mat Som ${ }^{1,2}$ \\ ${ }^{1}$ School of Housing, Building and Planning, Universiti Sains Malaysia, Malaysia \\ ${ }^{2}$ Sustainable Tourism Research Cluster (STRC), Universiti Sains Malaysia, Malaysia \\ Correspondence: Ahmad Rasmi Suleiman AlBattat, School of Housing, Building and Planning, Universiti Sains \\ Malaysia, Penang, Malaysia. Tel: 60-19-595-4499. E-mail: battat_ahmed@yahoo.com
}

Received: November 28, 2012

Accepted: December 18, 2012 Online Published: February 16, 2013

doi:10.5539/ijbm.v8n5p62

URL: http://dx.doi.org/10.5539/ijbm.v8n5p62

\begin{abstract}
Turnover crises have had great impacts on the hospitality industry. Many studies have been done on employee turnover, but further investigation is needed as labor intensive employees are part of the hospitality product. This study reviews the literature relevant to turn over crises and provides a theoretical review of the Mobley model (1977). The purpose of this study is to give an overview of the causes of job dissatisfaction which force an employee to quit from their current job and consider other job opportunities. This is to clarify the steps of the Mobley model from the feeling of job dissatisfaction to an actual turnover crisis. This study highlights the turnover crises not only on an international level but also the national crises in Malaysia which may not be far away. Furthermore, the findings from the literature review indicates that an international perspective on a turnover crisis begins when an employee faces the case of dissatisfaction from a poor working environment and considers leaving his current job. The Mobley model could be used to predict the case of dissatisfaction and better understand how to retain the employee. Further studies could be useful to shed light on turnover crises.
\end{abstract}

Keywords: Mobley model, Malaysia, turnover, crisis, hospitality

\section{Introduction}

Hospitality organizations need to constantly ensure the satisfaction of their employees (Berry, 1997). Organizations tend to be more effective when they satisfy their employees (Robbins \& Judge, 2007). Satisfied employees are deemed to be an effective labor force and become an important asset for the organization's effectiveness (Masri, 2009). Many Practitioners have examined organizational performance and the willingness of employees to have free work conditions (Organ, 1990; Tepper et al., 2001). According to Bharwani and Butt (2012), Human resources are one of the main parts of the product performing the difficult role of enhancing the organizational image. As in other industries, hospitality highly depends on humans having direct contact with their customers. In terms of the service model, there must be heterogeneity between the customers and their suppliers (Kusluvan et al., 2010). With the help of human resources, an organization will be able to enhance their business but due to employees various needs it becomes difficult to retain their employment, therefore, the focus on understanding their needs to achieve their satisfaction is essential (Masri, 2009).

According to Vroom (1964), job satisfaction is a positive direction an employee moves toward in his presently occupied working roles. Many studies have signaled that among the determinants of job satisfaction and organizational behavior (Cheng \& Yang, 1977; Darwish, 2000; Euske \& Jackson, 1980), comprehensive management encouragement (Burke, 2003; Burke \& Greenglass, 2001) is mentioned as a significant foreteller. (Rude, 2004) asserted that organizational support is highly linked to commanding behavior, hence, defined support from a manager is a significant factor in labor turnover (Maslach et al., 2001; Rude, 2004).

The employee's dissatisfaction will affect their commitment to work and lead them to turnover from the organization physically and/or mentally (Pathak, 2012). Tracey and Hinkin (2008) stated that employee turnover rates are influenced by employee dissatisfaction within the job environment and reduce their contribution to the job (Lok \& Crawford, 2004). Many scholars have studied the consequences which probably have forced an employee into a quitting decision. This is followed by evaluating other work environments which will lead to the intention of seeking other opportunities (Lee, 1988). Often, turnover cost affects the organization (Connolly \& Connolly, 1991; Tracey \& Hinkin, 2008). 
This paper identified factors affecting Hospitality labor satisfaction which may lead them to turn over. First, it explored the existing literature about job satisfaction and turnover intention. Second, a brief rehearsal of the Mobley model (1977) applications studying the factors leading to turnover crises is given. The paper further examined whether Malaysian Hospitality and tourism sector could apply Mobley model to reduce these crises.

\section{Methodology}

This study attempts to review the existing literature on hospitality and tourism employment, working environments, labor turnover, employment factors, employee dissatisfaction, and the causes of turnover crises. The Mobley model (1977) and a theoretical framework interpreting the relationship between work environment, employee satisfaction, turnover intention which leads to an actual voluntary or involuntary turnover will also be examined. A further review of the effect of turnover crises on the quality of service and customer loyalty will be addressed. To enrich the discussions, the results of the theoretical studies undertaken by the authors have been used.

\section{Literature Review}

\subsection{Employment Environment}

This paper is based on conceptual work and the data is from a collection of books and published journals within the hospitality human resource management to aid in reinterpreting the existing concepts (Chaudhary, 1991). Many researchers have studied the impacts of work satisfaction on hospitality employees. (Bharwani \& Butt, 2012) evaluated the challenges in hospitality organizations and its overall impact on labor.

According to Davies et al. (2001), performance appraisals, remunerations and training are important human resource practices in Australian hotels. They asserted that the commitment to an organization could be better when adapting a suitable HR system; improving good labor relations and quality of service. Lauver and Kristof-Brown (2001) investigated the unique relationship and impacts of person-job and person-organization suitability on job satisfaction and the intent to quit. Job satisfaction is defined as the influential reaction to different forms of a job or organization (Locke, 1976).

Some practitioners clarified the dimensions of organizational justice in the relevant literature. Three dimensions were studied: distributive, procedural, and interactional (Cohen-Charash \& Spector, 2001; Erdogan, 2003). Many scholars were in favor of the justice dimensions with regard to employees' satisfaction, commitment toward the organization, and the intent to turn over (Hemdi \& Mohd, 2007). A literature scan of hospitality and tourism management discovered that job satisfaction, organizational obligation, and turnover intentions are the results of organizational justice dimensions (Fulford, 2005; Hemdi \& Mohd, 2007; Nadiri \& Tanova, 2010). Other scholars have examined the impacts of job satisfaction on employee turnover within the Amari Hotels in Thailand (Ronra \& Chaisawat, 2010 ). They observed the relationship between employee satisfaction and their overall satisfaction giving suggestions to help reduce the turnover rate. WeiBo et al. (2010) evaluated the literature of previous scholars on employee retention.

Work stress continues to gain the attention of many researchers. They have focused on the types of stress and the reasons which led the employees to acquire stress in their work environment. Researchers have also employed strategies to confront stress (Pestonjee, 1992). Work stress, burnout, and labor turnover have become commonly known words in the study of human resources (Banet et al., 2005; Sharma et al., 2010). Researchers have asserted that there are direct and indirect costs of work stress which could lead to the crucial problems of labor, employers, and the community (Matteson \& Ivancevich, 1982). Thus, some factors are associated with the stress; such as the lack of power, role ambiguity, and conflict (Burke, 1988; Nelson \& Burke, 2000). Other researchers have identified stress as a critical issue in many organizations (Cooper \& Cartwright, 1994; Ornelas \& Kleiner, 2003; Varca, 1999). On the other hand, role ambiguity has become another factor of work stress. According to (Beehr et al., 1976; Cooper, 1991; Cordes \& Dougherty, 1993; Dyer \& Quine, 1998; Ursprung, 1986), role ambiguity occurs when an employee has a shortage of information about his work requirements.

Demographic factors have also gained vast amounts researchers' concern. (Bluedorn, 1979; Elangovan, 2001) highlighted the demographic factors: employee's age, gender, race, education, and marital status that clout job expectations; satisfaction which eventually affects job dissatisfaction, and labor turnover. Whereas, women and other minority groups have faced many problems in the work environment regarding different expectations of justice and equality which can lead to discrimination in wages, rewards, and compensation (Valentine, 2001).

\subsection{Turnover Crises}

Labor turnover has become a critical problem for the hospitality industry mainly because of its dependency on the "human factor". Therefore, because of the financial and moral effects on hospitality organizations, many 
researchers have focused on these issues in the last few decades. Researchers such as (Kuria et al., 2012) studied the internal and external causes of employee turnover in Kenyan hotels located in Nairobi. They directed their attention to the work umbrage, unfavorable working conditions, stress, long working hours with minimal wages, and poor training programs. (Seta et al., 2000) indicated the factors affecting employees' satisfaction, and the organization's role to enhance an employees' commitment toward the organization. They argued that proper training, work progress, and compensation could improve employees` satisfaction toward the organization.

According to (Fair, 1992; Kivela \& Go, 1996; Shaw, 2011) the inadmissible, high labor turnover rate, content may shape the relationship between turnover rates and performance reduction in human capital. Scholars such as (Angel \& Cannella, 2004) asserted that the wage factor produced the major intent for turnover. They mentioned that the Yellen (1984) model can be integrated the with turnover theories. Other practitioners, (Lam et al., 2003; MacIntosh \& Doherty, 2010; Martin, 2011; Robinson \& Beesley, 2010), argued that the intention to quit begins when the employee has received an unfavorable situation and starts thinking about another job. Developing new program consumes company funds when trying to solve labor problems before they become too serious and lead to turnover (Price, 1977).

Turnover intention is the crucial stage before the actual turnover occurs. Unmet expectations can lead to turnover intentions which force the employee to ultimately quit. According to (Bigliardi et al., 2005), labor with the intention to quit from their current job occur after individuals start thinking about staying or to leave; though in the short term, employees could have high intentions to quit (Mowday et al., 1979). Leaving the organization is much easier than the intention to leave (Blau, 2000). Voluntary or involuntary turnover will be the final decision of the employee.

Voluntary turnover is the termination of the official and the psychological contract between the employee and the organization (Krausz, 2002; Macdonald, 1999; McLean Parks et al., 1999; Rousseau, 1995). It has become a problem with all jobs but considered serious with effect to the service sector (Lee, 1988). Within this case, researchers have argued that high turnover is a critical problem in the hospitality industry (Nadiri \& Tanova, 2010). Poor management, low wages, bad working environment, and paucity of job opportunities could be the highest causes of turnover (Haven-Tang \& Jones, 2012; Kusluvan et al., 2010). Involuntary turnover inescapably leads to direct negative results; such as job insecurity, work difficulty, and status fluctuation. This passive reaction exists for all employees who recently lost their jobs (Gowan \& Gatewood, 1997).

\subsection{Mobley Model (1977)}

Hospitality is considered as an unstable industry due to its dependency on human factors according to considerable amounts of previous research. (Kuria et al., 2012) concentrated their research on labor turnover in Kenyan hotels regarding the job discontent of the workers. They experienced bad working environments, fatigue, stress, low wages and a deficiency in training.

Much research on turnover has been done in different parts of the world, for example, (Fair, 1992; Kivela \& Go, 1996; Shaw, 2011) presented the prosperous literature on turnover rates while reviewing the TQM applications needed by the organizations. By examining the inadmissibly high turnover rates, reviewing past cases, and the leakage in labor, they asserted that TQM applications could influence the quality and organizational structure of a company. Additionally, (Angel \& Cannella, 2004) studied the salary factors and its effect on turnover intentions and they asserted that the wage model developed by (Yellen, 1984) provided an efficient means for study. They suggested that this model could be integrated within turnover theories.

(Lam et al., 2003; MacIntosh \& Doherty, 2010; Martin, 2011; Robinson \& Beesley, 2010) explained that the intention to quit started by searching for other jobs after a feeling of dissatisfaction arose with the current position. (Bowen \& Siehl, 1997), in their study supported the outcomes of March \& Simon (1958), by demonstrating the final decision to quit occurs after a dissatisfied situation level is reached by an employee to cause a change in his workplace for the better. According to Price (1977), experts developed programs and financed large amounts in the aim to solve these problems before they become a major issue leading to turnovers.

Many previous studies have been explained by the Mobley Model (1977) proposing steps for employees steering towards dissatisfaction and quitting their job, Seven stages were determined between job satisfaction and turnover (Lee, 1988). Mobley asserted that these steps started when an employee faced a case of dissatisfaction which led them to think about quitting from their current job as well as searching and evaluating alternative job environments. Little or deep though of these considerations usually depend on the cost of turnover. If the turnover cost is acceptable, an employee's situation will lead toward turnover crises (Lee, 1988; Martin, 2011; P. Muchinsky, 1993). In their study, (Hom et al., 1984) analyzed the seven stages of the Mobley 
model. The validity of their analysis was conducted on incomplete information but the results were more reliable from the preparatory level of trust of the Mobley model.

Pearson (1991) explained that it is difficult to know why labor turnover occurs because it is related to human factors. Even management could not identify the reasons for the 'exit interviews'. The management commitment toward the employee turnover uses the seven stages of the Mobley model and supports the validity of the theory. Therefore, the commitment to employees' job satisfaction enhances the relationships between job satisfaction and involvement will then lead to the reduction of turnover crises. Figure (1) explains the Mobley Model (1977) idea.

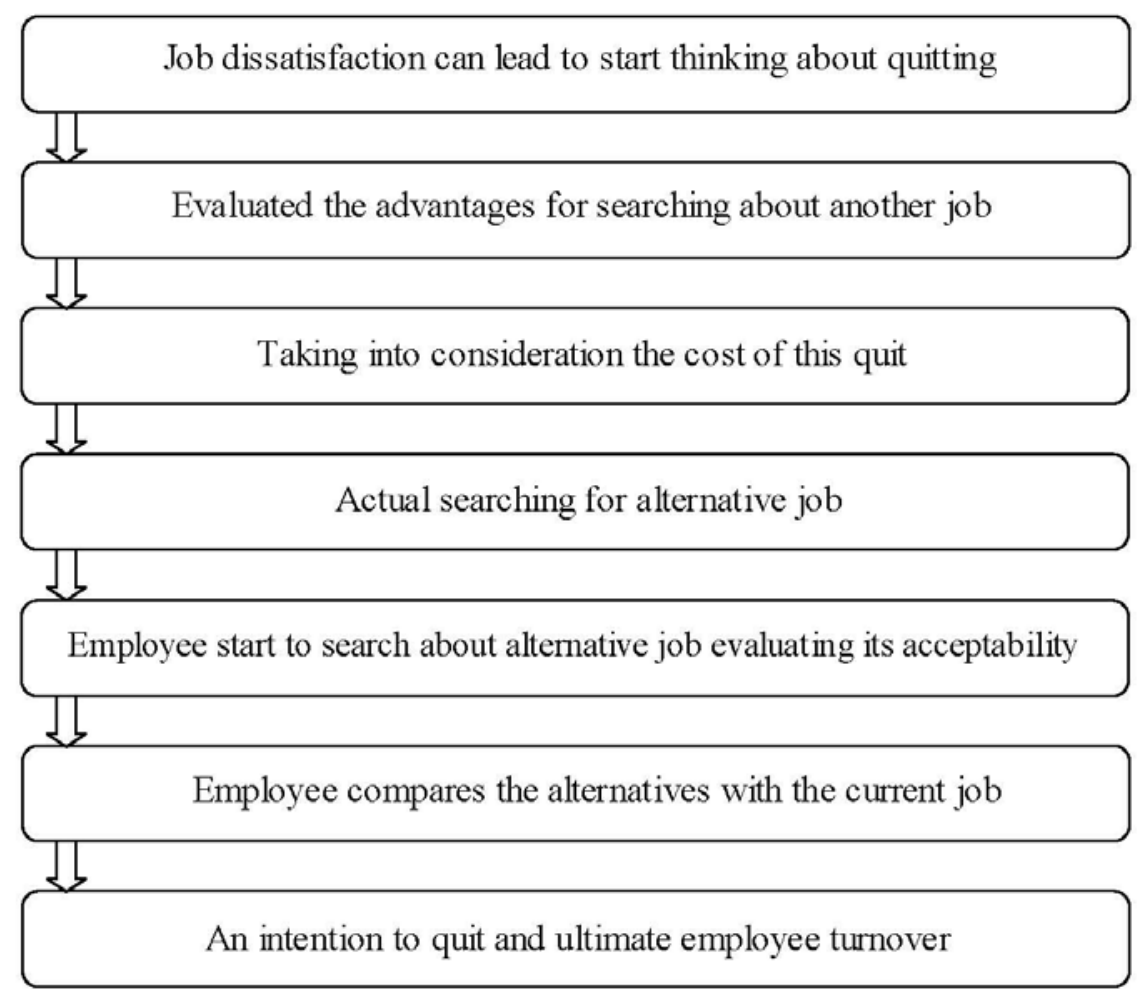

Figure 1. Employee dissatisfaction steps to turn over, adopted by (Mobley 1982)

The Mobley model was not offered as solid stages employees could walk through; some cases could be different. To avoid turnover crises, the Malaysian regime knows the contribution needed in the hospitality and tourism industry for sustaining the economy: its crucial regulations. Further studies should be done to enhance the employment environment in order to reduce turnover crises. 


\section{Theoretical Framework}

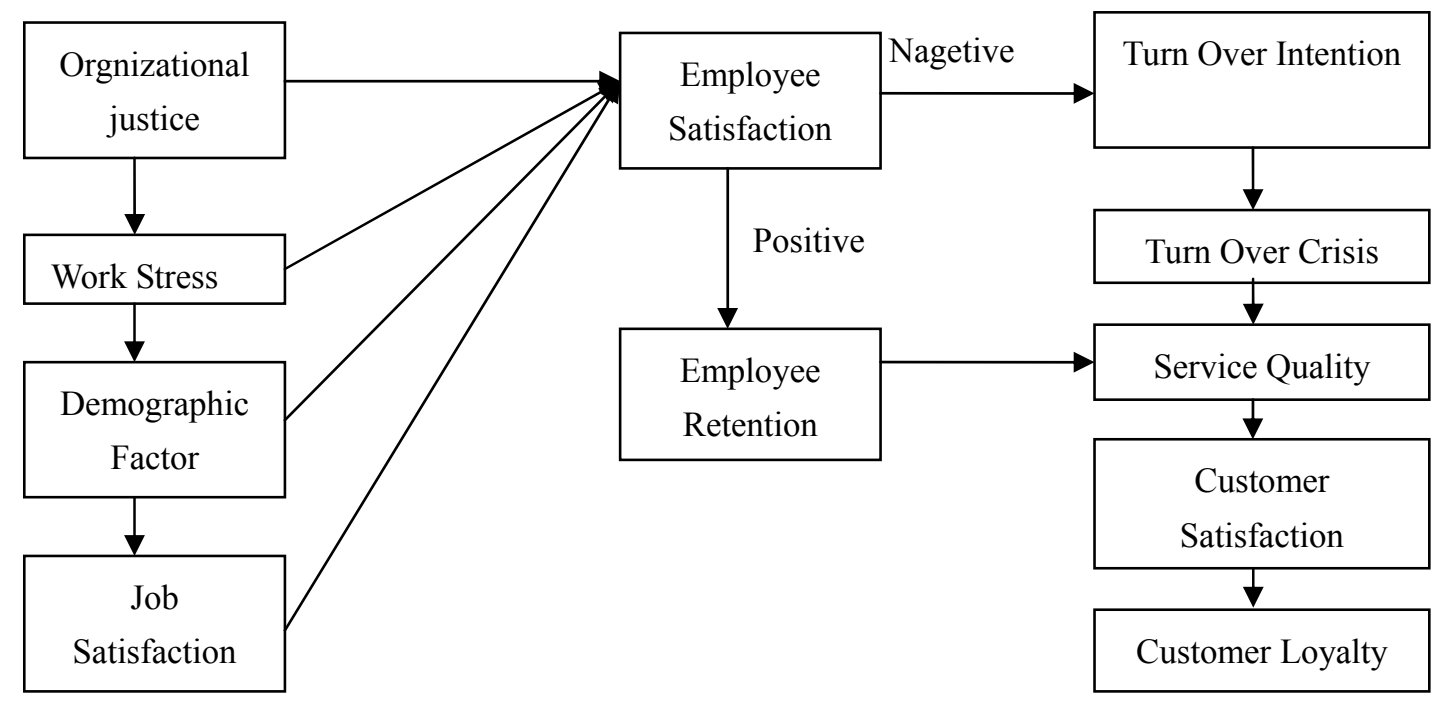

Figure 2. Relationship between employee satisfaction and turnover crises

The study theoretical framework has been adopted from (Mobley 1982) and enhanced by (Kuria et al., 2012; P. Muchinsky, 1993, p.310; WeiBo et al., 2010) and to output a suitable framework to measure the relationship between all factors of employee satisfaction. Many practitioners have defined turnover as the change in jobs and careers done by the employees who have received salaries from organizations (Kuria et al., 2012; Mobley 1982; Ronra \& Chaisawat, 2010 ; WeiBo et al., 2010).

Referring to the previous studies, many researchers, conceptual and empirical studies have highlighted the jobs' liabilities, training programs, organizational environment, work relations, and work dissatisfaction which all lead to employee burnout (Bonn \& Forbringer, 1992; Foong-ming, 2008; Mobley et al., 1979; Tracey \& Hinkin, 2008; Williams \& Hunter, 1992). Some researchers have argued that the labor performance in the workplace will be affected by the employee relations within the work environment. Employee retention was highlighted as the result of job satisfaction, whereas, turnover crises and work termination are the final decisions after facing bad working conditions (Mobley et al., 1978).

As mentioned above, the study's theoretical framework illustrates the effects of organizational justice, job stress, and the demographic factors for employees`satisfaction. Many researchers have illustrated that job satisfaction will lead to employee retention while the job dissatisfaction forces turnover intention. Whether the turnover was voluntary or involuntary, a turnover crisis will influence the employee retention affecting the service quality and customer loyalty (Cho et al., 2006; Katou \& Budhwar, 2007; Tsaur \& Lin, 2004).

\section{Findings and Discussions}

The study attempts to seek out the impacts of a working environment, job stress, demographic factors, and job satisfaction on employee satisfaction. The Mobley model (1977) explains the seven stages of job dissatisfaction and actual turnover; presented with its applications in the Malaysian hospitality sector. This model theorized that job dissatisfaction probably leads the employee to consider leaving their present employment then evaluating the cost of moving from his job to another. Turnover intention will lead an employee to make comparisons between the current and the future job. Finally, this intention will lead them to the actual turnover (Lee, 1988; Robinson \& Beesley, 2010; Tracey \& Hinkin, 2008).

Malaysia is moving from the productive economy to the knowledge economy. The global changes have affected all industries forcing them to provide better services. The hospitality and tourism sectors are very important to the Malaysian economy as the service industry is highly dependent on human labor; which must be satisfied in order to gain from their commitment and retention. From their point of view, (Foong-ming, 2008; Richardson \& Butler, 2011) mentioned that a strong relationship between employee satisfaction and employee retention will directly affect customer satisfaction and the quality of services. The valuable findings from the literature could be applied to the Malaysian hospitality industry in order to evaluate the current human resource situation. This 
may, in time, maximize employee satisfaction and avoid turnover crises.

According to the economic transformation program, the hospitality industry employs a considerable number of people rated at $14 \%$ from the total Malaysian labor force. A lower average salary compared with other sectors who work in Malaysian Hospitality earn an average monthly salary of RM 1,084 compared to RM 2,114 in the financial services and to RM 2,621 in the energy sector. This data gave them the incentive to resign from their current employment and search about other industries (NKEA, 2010).

The stakeholders in the Malaysian hospitality sector should be aware of these findings and use training in an attempt to satisfy their employees in an effort to receive their loyalty and delivery of good services. An ultimate goal would be to gain customer satisfaction and loyalty. This is consistent with (Carrell et al., 1992; Dario, 1989; Milkovich \& Boudreau, 1997), who asserted that organizations should attract qualified employees, evaluate their salary policies, create an intensive rewards scheme, and enhance a good supervisory and communication system in order to satisfy their employees and reduce the turnover rates.

\section{Conclusion}

This study attempts to present the impacts of demographic factors, salaries and wages, and the organizational environment on employee satisfaction. It also aims to discover whether job dissatisfaction could lead to turnover intention which will lead the employee to the actual turnover and leave their present employment. Much literature has been previously done to investigate labor satisfaction, turnover intention, and customer loyalty. The Malaysian hospitality and tourism industry should be aware of the Mobley model and its applications as its one of the most valid models which explains the series an employee transitions when faced with the case of dissatisfaction. Moreover, Mobley assumed that the case of employee dissatisfaction will come from unacceptable working conditions, low salaries, and injustice, influencing them to quit. Based on the literature review, a theoretical framework has been developed. This study attempted to explain the Mobley Model and encouraged the Malaysian hospitality stakeholders to review and develop their employment strategies to reduce the effects of turnover crises.

As expected, the findings of the study based on the literature review supported the Mobley Model and its applications. The findings also suggested that Malaysian hospitality stakeholders should recognize that poor working conditions, low salaries, and injustice will lead an employee to turnover and change job.

Identical results have been found from the study of (Hemdi et al., 2012; Lam et al., 2003; Pathak, 2012) which revealed that bad working conditions, low salaries, work stress, and injustice between the employees will help them consider the idea of leaving their work to cause an actual turnover.

\section{Acknowledgments}

The authors would like to extend their appreciation to the Universiti Sains Malaysia for the Research University Grant under the Sustainable Tourism Research Cluster STRC entitled 'Tourism Planning' [Grant No. 1001/PTS/8660013] which made this study and paper possible.

\section{References}

Angel, P., \& Cannella, A. (2004). Executive Turnover Revisited From an Efficiency Wage Perspective. The Journal of the Iberoamerican Academy of Management, 2(1), 7-23.

Banet, Plint, \& Clifford. (2005). Reducing stress and avoiding burnout: A collection of activities for preschoolers.

Beehr, T., Walsh, J., \& Taber, T. (1976). Perceived situational moderators of the relationship between subjective role ambiguity and role strain. Journal of Applied Psychology, 61(1), 35-40. http://dx.doi.org/10.1037/0021-9010.61.1.35

Berry, L. (1997). Psychology at work. San Francisco: McGraw-Hill Companies Inc.

Bharwani, S., \& Butt, N. (2012). Challenges for the global hospitality: an HR perspective. Worldwide Hospitality and Tourism Themes, 4(2), 150-162. http://dx.doi.org/10.1108/17554211211217325

Bigliardi, B., Petroni, A., \& Dormio, A. (2005). Organizational socialization, career aspirations and turnover intentions among design engineers. Leadership \& Organization Development Journal, 26(6), 424-441. http://dx.doi.org/10.1108/01437730510617645

Blau, G. (2000). Job, organizational and professional context antecedents as predictors of intent for interrole work transitions. Journal of Vocational Behavior, 56(3), 330-345. http://dx.doi.org/10.1006/jvbe.1999.1718 
Bluedorn, A. (1979). Structure, environment, and satisfaction: toward a causal model of turnover from military organizations. Journal of Military and Political Sociology, 7, 181-207.

Bonn, M. A., \& Forbringer, L. R. (1992). Reducing turnover in the hospitality industry: an overview of recruitment, selection and retention. International Journal of Hospitality Management, 11(1), 47-63. http://dx.doi.org/10.1016/0278-4319(92)90035-T

Bowen, D. E., \& Siehl, C. (1997). The future of human resource management: March and Simon (1958) revisited. Human Resource Management, 36-63. http://dx.doi.org/10.1002/(SICI)1099-050X(199721)36:1<57::AID-HRM10>3.0.CO;2-B

Burke, R. (1988). Sources of managerial and professional stress in large organizations. Causes, Coping and Consequences of Stress at Work, 77-114. http://dx.doi.org/10.1108/01443330310790679

Burke, R. (2003). Nursing staff attitudes following restructuring: the role of perceived organizational support, restructuring processes and stressors. International Journal of Sociology and Social Policy, 23(8/9), 129-157.

Burke, R., \& Greenglass, E. (2001). Hospital restructuring and nursing staff well-being: The role of perceived hospital and union support, Anxiety, Stress and Coping. An International Journal, 14(3), 93-115.

Carrell, M., Kuzmits, F., \& Elbert, N. (1992). Personal Human Resource Management (4th ed.). New York: MacMillan Publishing Company.

Chaudhary, C. (1991). Research Methodology. Jaipur: S. K. Parnami, R. B. S. A. Publishers.

Cheng, B., \& Yang, K. (1977). Supervisory behavior, skill level, and interpersonal dominance as determinants of job satisfaction. Bulletin of the Institute of Ethnology, 44, 13-45.

Cho, S., Woods, R. H., Jang, S., \& Erdem, M. (2006). Measuring the impact of human resource management practices on hospitality firms' performances. International Journal of Hospitality Management, 25(2), 262-277. http://dx.doi.org/10.1016/j.ijhm.2005.04.001

Cohen-Charash, Y., \& Spector, P. (2001). The role of justice in organizations: A meta-analysis. Organizational Behavior and Human Decision Processes, 86(2), 278-321. http://dx.doi.org/10.1006/obhd.2001.2958

Connolly, K. G., \& Connolly, P. M. (1991). Competing for employees: proven marketing strategies for hiring and keeping exceptional people. Toronto: Lexington Books.

Cooper, C. (1991). Stress in organizations. In M. Smith (Ed.), Analysing Organizational Behaviour. London: MacMillan.

Cooper, C., \& Cartwright, S. (1994). Stress-management interventions in the workplace: Stress counselling and stress audits. British Journal of Guidance and Counselling, 22(1), 65-73.

Cordes, C., \& Dougherty, T. (1993). A review and an integration of research on job burnout. Academy of Management Review, 18(4), 621-656.

Dario, M. (1989). Personal Manager’s Desk Book. New Jersey: Prentice Hall.

Darwish, Y. (2000). Organizational commitment: a mediator of the relationships of leadership behavior with job satisfaction and performance in a non-western country. Journal of Managerial Psychology, 15(1), 6-24. http://dx.doi.org/10.1108/02683940010305270

Davies, D., Taylor, T., \& Savery, L. (2001). The role of appraisal, remuneration and training in improving staff relations in the Western Australian accommodation industry: a comparative study. Journal of European Industrial Training, 25(7), 366-373. http://dx.doi.org/10.1108/EUM0000000005837

Dyer, S., \& Quine, L. (1998). Predictors of job satisfaction and burnout among the direct care staff of a community learning disability service. Journal of Applied Research in Intellectual Disabilities, 11(4), 320-332. http://dx.doi.org/10.1111/j.1468-3148.1998.tb00040.x

Elangovan, A. (2001). Causal ordering of stress, satisfaction and commitment, and intention to quit: a structural equations analysis. Leadership \& Organization Development Journal, 22(4), 159-165. http://dx.doi.org/10.1108/01437730110395051

Erdogan, B. (2003). Antecedents and consequences of justice perceptions in performance appraisals. Human Resource Management Review, 12(4), 555-578. http://dx.doi.org/10.1016/S1053-4822(02)00070-0

Euske, K., \& Jackson, D. (1980). Performance and satisfaction of bank managers. Journal of Bank Research, 
11(1), 36-42.

Fair, R. (1992). Australian Human Resources management: framework and practice (2nd ed.). Sidney: McGraw-Hill.

Foong-ming, T. (2008). Linking Career Development Practices to Turnover Intention: The Mediator of Perceived organizational support. Journal of Buisness and Public Affairs, 2(1).

Fulford, M. D. (2005). That's Not Fair! the test of a model of organizational justice, job satisfaction, and organizational commitment among hotel employees. Journal of Human Resources in Hospitality \& Tourism, 4(1), 73-84. http://dx.doi.org/10.1300/J171v04n01_06

Gowan, M., \& Gatewood, R. (1997). A model of response to the stress of involuntary job loss. Human Resource Management Review, 7(3), 277-297. http://dx.doi.org/10.1016/S1053-4822(97)90009-7

Haven Tang, C., \& Jones, E. (2012). Local leadership for rural tourism development: A case study of Adventa, $\begin{array}{llll}\text { Monmouthshire, UK. Tourism } \quad \text { Management } & \text { Perspectives, 35. }\end{array}$ http://dx.doi.org/10.1016/j.tmp.2012.04.006

Hemdi, M., \& Mohd, A. (2007). Investigating the influence of organizational justice on hotel employees' organizational citizenship behavior intentions and turnover intentions. Journal of Human Resources in Hospitality \& Tourism, 7(1), 1-23. http://dx.doi.org/10.1300/J171v07n01_01

Hemdi, M., Omar, M., \& Azmi, A. (2012, 12-13 March). The effect of organizational justice and organizational trust on hotel employees turnover intentions. Paper presented at the 3rd International conference on business and economic research (3rd ICBER 2012), Golden flower hotel, Bandung, Indonesia.

Hom, P. W., Griffeth, R. W., \& Sellaro, C. L. (1984). The validity of mobley's (1977) model of employee turnover. Organizational Behavior and Human Performance, 34(2), 141-174. http://dx.doi.org/10.1016/0030-5073(84)90001-1

Katou, A. A., \& Budhwar, P. S. (2007). The effect of human resource management policies on organizational performance in Greek manufacturing firms. Thunderbird International Business Review, 49(1), 1-35. http://dx.doi.org/10.1002/tie.20129

Kivela, J., \& Go, F. (1996). Total Quality Management Transfer: A Case of Hong Kong Hotels. Asia Pacific Journal of Human Resources, 34(1), 63-76. http://dx.doi.org/10.1177/103841119603400104

Krausz, M. (2002). The many faces of voluntary employee turnover. Voluntary Employee Withdrawal And Inattendance, 53-70. http://dx.doi.org/10.1007/978-1-4615-0599-0_3

Kuria, S., Alice, O., \& Wanderi, P. (2012). Assessment of causes of Labour Turnover in Three and five Star-Rated Hotel in Kenya. International Journal of Bussiness and Social Science, 3(15), 311-317.

Kusluvan, S., Kusluvan, Z., Ilhan, I., \& Buyruk, L. (2010). The Human Dimension A Review of Human Resources Management Issues in the Tourism and Hospitality Industry. Cornell Hospitality Quarterly, 51(2), 171-214. http://dx.doi.org/10.1177/1938965510362871

Lam, T., Baum, T., \& Pine, R. (2003). Subjective norms: Effects on Job Satisfaction. Annals of Tourism Research, 30(1), 160-177. http://dx.doi.org/10.1016/S0160-7383(02)00047-6

Lee, T. (1988). How job dissatisfaction leads to employee turnover. Journal of Business and Psychology, 2(3), 263-271. http://dx.doi.org/10.1007/BF01014043

Locke, E. (1976). The nature and causes of Job Satisfaction. In Dunnette, M. D. (Ed.), Handbook of organizational and industrial psychology. Chicago. Rand. Mc. Nally.

Lok, P., \& Crawford, J. (2004). The effect of organisational culture and leadership style on job satisfaction and organisational commitment: A cross-national comparison. Journal of Management Development, 23(4), 321-338. http://dx.doi.org/10.1108/02621710410529785

Macdonald, D. (1999). Teacher attrition: A review of literature. Teaching and Teacher Education, 15(8), 835-848. http://dx.doi.org/10.1016/S0742-051X(99)00031-1

MacIntosh, E. W., \& Doherty, A. (2010). The influence of organizational culture on job satisfaction and intention to leave. Sport Management Review, 13(2), 106-117. http://dx.doi.org/10.1016/j.smr.2009.04.006

Martin, M. J. (2011). Influence of Human Resource Practices on Employee Intention to Quit. Virginia Polytechnic Institute and State University. 
Maslach, C., Schaufeli, W., \& Leiter, M. (2001). Job burnout. Annual review of psychology, 52(1), 397-422. http://dx.doi.org/10.1146/annurev.psych.52.1.397

Masri, M. (2009). Job satisfaction and turnover intention among the skilled personnel in TRIplc BERHAD. (Master), University Utara Malaysia.

Matteson, M. T., \& Ivancevich, J. M. (1982). Managing job stress and health: The intelligent person's guide. Free Press New York.

McLean Parks, J., Kidder, D., \& Gallagher, D. (1999). Fitting square pegs into round holes: Mapping the domain of contingent work arrangements onto the psychological contract. Journal of organizational Behavior, 19(S1),

697-730. http://dx.doi.org/10.1002/(SICI)1099-1379(1998)19:1+<697::AID-JOB974>3.0.CO;2-I

Milkovich, G., \& Boudreau, J. (1997). Human Resource Management (8th ed.). New York: Irwin McGraw-Hill.

Mobley, W. (1982). Employee Turnover, Causes, Consequences, and Control. Addison-Wesley.

Mobley , W., Horner, S., \& Hollingsworth, A. (1978). An evaluation of precursors of hospital employee turnover. Journal of Applied Psychology, 63(4), 408-414. http://dx.doi.org/10.1037/0021-9010.63.4.408

Mobley, W. H., Griffeth, R. W., Hand, H. H., \& Meglino, B. M. (1979). Review and conceptual analysis of the employee turnover process. Psychological Bulletin, 86(3), 493-522. http://dx.doi.org/10.1037/0033-2909.86.3.493

Mowday, R., Steers, R., \& Porter, L. (1979). The measurement of organizational commitment. Journal of Vocational Behavior, 14(2), 224-247. http://dx.doi.org/10.1016/0001-8791(79)90072-1

Muchinsky, P. (1993). Psychology Applied to Work (4th ed.). California: Brooks/Cole publishing company.

Nadiri, H., \& Tanova, C. (2010). An investigation of the role of justice in turnover intentions, job satisfaction, and organizational citizenship behavior in hospitality industry. International Journal of Hospitality Management, 29(1), 33-41. http://dx.doi.org/10.1016/j.ijhm.2009.05.001

Nelson, D., \& Burke, R. (2000). Women executives: Health, stress, and success. The Academy of Management Executive (1993-2005), 14(2), 107-121.

NKEA. (2010). Economic transformation programme a roadmap for Malaysia, Revving Up the Tourism Industry. Retrieved from http://etp.pemandu.gov.my/upload/etp_handbook_chapter_10_tourism.pdf

Organ, D. W. (1990). The subtle significance of job satisfaction. Clinical Laboratory Management Review, 4(1), 94-98.

Ornelas, S., \& Kleiner, B. (2003). New developments in managing job related stress. Equal Opportunities International, 22(5), 64-70. http://dx.doi.org/10.1108/02610150310787504

Pathak, D. (2012). Role of perceived organizational support on stress-satisfaction relationship: An empirical study. Asian Journal of Management Research, 3(1), 153-177.

Pearson, R. (1991). The human resource: managing people and work in the 1990's. London: McGraw-Hill.

Pestonjee, D. (1992). Stress and coping: The Indian experience. New Delhi, India: Sage Publication.

Price, J. L. (1977). The study of turnover. Iowa State University Press.

Richardson, S., \& Butler, G. (2011). Attitudes of Malaysian Tourism and Hospitality Students' towards a Career in the Industry. Asia Pacific Journal of Tourism Research, 17(3), 262-276. http://dx.doi.org/10.1080/10941665.2011.625430

Robbins, S., \& Judge, T. (2007). Organizational Behaviour (12th ed.). New Jersey: Pearson Education, Inc.

Robinson, R. N. S., \& Beesley, L. G. (2010). Linkages between creativity and intention to quit: An occupational study of chefs. Tourism Management, 31(6), 765-776. http://dx.doi.org/10.1016/j.tourman.2009.08.003

Ronra, B., \& Chaisawat, M. (2010). Factors Affecting Employee Turnover and Job Satisfaction: A Case Study of Amari Hotels and Resorts. Paper presented at the 3rd International Colloquium on Business \& Management (ICBM), Bangkok, Thailand.

Rousseau, D. (1995). Psychological contracts in organizations: Understanding written and unwritten agreements. Sage Publications, Incorporated.

Rude, W. (2004). The connection between servant leadership and job burnout, Servant Leadership Research 
Roundtable. Trinity Western University, School of Leadership Studies.

Seta, C., Paulus, P., \& Baron, R. (2000). Effective Human Resource Relations: A Guide to People at Work (4th ed.). USA: Allyn and Bacon.

Sharma, A., Verma, S., Verma, C., \& Malhotra, D. (2010). Stress and Burnout as Predictors of Job Satisfaction among Lawyers. European Journal of Social Sciences, 14(3), 348-359.

Shaw, J. (2011). Turnover rates and organizational performance: Review, critique, and research agenda. Organizational Psychology Review, 1, 187-213. http://dx.doi.org/10.1177/2041386610382152

Tepper, B. J., Lockhart, D., \& Hoobler, J. (2001). Justice, citizenship, and role definition effects. Journal of Applied Psychology, 86(4), 789-796. http://dx.doi.org/10.1037/0021-9010.86.4.789

Tracey, B., \& Hinkin, T. (2008). Contextual factors and cost profiles associated with employee turnover. Cornell Hospitality Quarterly, 49(1), 12-27. http://dx.doi.org/10.1177/0010880407310191

Tsaur, S. H., \& Lin, Y. C. (2004). Promoting service quality in tourist hotels: the role of HRM practices and service behavior. Tourism Management, 25(4), 471-481. http://dx.doi.org/10.1016/S0261-5177(03)00117-1

Ursprung, A. (1986). Incidence and correlates of burnout in residential service settings. Rehabilitation Counseling Bulletin, 29, 225-239.

Valentine, S. (2001). A path analysis of gender, race, and job complexity as determinants of intention to look for work. Employee Relations, 23(2), 130-146. http://dx.doi.org/10.1108/01425450110384507

Varca, P. (1999). Work stress and customer service delivery. Journal of Services Marketing, 13(3), 229-241. http://dx.doi.org/10.1108/08876049910273853

Vroom, V. (1964). Work and Motivation. New York: John Willey.

WeiBo, Z., Kaur, S., \& Zhi, T. (2010). A critical review of employee turnover model (1938-2009) and development in perspective of performance. African journal of Business Management, 4(19), 4146-4158.

Williams, P., \& Hunter, M. (1992). Supervisory hotel employee perceptions of management careers and professional development requirements. International Journal of Hospitality Management, 11(4), 347-358. http://dx.doi.org/10.1016/0278-4319(92)90051-V

Yellen, J. (1984). Efficiency wage models of unemployment. Information and Macroeconomics, 74(2), 200-205. 